\title{
THERAPY OF ENDOCRINE DISEASE
}

\section{Growth hormone replacement therapy in adults: $\mathbf{3 0}$ years of personal clinical experience}

\author{
Jens O L Jørgensen ${ }^{1}$ and Anders Juul² \\ 1Department of Endocrinology and Internal Medicine, Aarhus University Hospital, Aarhus, Denmark and \\ ${ }^{2}$ Department of Growth and Reproduction, Rigshospitalet, University of Copenhagen, Copenhagen, Denmark
}

\author{
Correspondence \\ should be addressed \\ to J O L Jørgensen \\ Email \\ joj@clin.au.dk
}

\section{Abstract}

The acute metabolic actions of purified human growth hormone (GH) were first documented in adult hypopituitary patients more than 50 years ago, and placebo-controlled long-term GH trials in GH-deficient adults (GHDA) surfaced in 1989 with the availability of biosynthetic human GH. Untreated GHDA is associated with excess morbidity and mortality from cardiovascular disease and the phenotype includes fatigue, reduced aerobic exercise capacity, abdominal obesity, reduced lean body mass, osteopenia and elevated levels of circulating cardiovascular biomarkers. Several of these features reverse and normalize with GH replacement. It remains controversial whether quality of life, assessed by questionnaires, improves. The known side effects are fluid retention and insulin resistance, which are reversible and dose dependent. The dose requirement declines markedly with age and is higher in women. Continuation of GH replacement into adulthood in patients with childhood-onset disease is indicated, if the diagnosis is reconfirmed. GH treatment of frail elderly subjects without documented pituitary disease remains unwarranted. Observational data show that mortality in GH-replaced patients is reduced compared to untreated patients. Even though this reduced mortality could be due to selection bias, GH replacement in GHDA has proven beneficial and safe.

\section{Introduction}

A growth-promoting activity of anterior pituitary extracts was discovered almost a 100 years ago by Evans and Long, and growth hormone (GH) was isolated in 1944 and tested in human subjects by several groups (1). It became evident that species-specific differences existed and that only human and - to some extent - simian GH are active in man. The protein anabolic and lipid catabolic effects of $\mathrm{GH}$ were comprehensively tested by Maurice Raben and summarized in two seminal publications in 1962, which are recommendable readings owing to their

\section{Invited Author's profile}

Jens Otto Lunde Jorgensen is Prof. and Chair of the Department of Clinical Medicine and the Department of Endocrinology and Diabetes, Aarhus University Hospital, Denmark. Prof. Jørgensen's main research interests include growth hormone (GH), GH deficiency, metabolic actions of GH and acromegaly, with further work in insulin resistance states, obesity, Cushing and ghrelin.

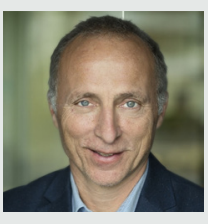

(C) 2018 European Society of Endocrinology Printed in Great Britain
Published by Bioscientifica Ltd. 
clarity and prophetic strengths $(2,3)$. He was the first to hypothesize that GH replacement therapy in adults with hypopituitarism could be beneficial (3). Subsequently, GH extracted from human cadaveric pituitaries was used therapeutically to promote longitudinal growth in children with hypopituitarism and severe growth retardation, but the limited supply precluded the exploration of other indications. The use of pituitary human GH was halted in several countries in 1985 since it was associated with transmission of Creutzfeld-Jakob disease (4), which accelerated the approval of biosynthetic human GH, that first proved efficacious in GH-deficient children (5). This radically changed the scene by providing a potentially unlimited supply of pure and uncontaminated GH. In response to this, James Tanner, a leading expert in pediatric growth disorders and auxology, stated 'We are now moving from an era in which there were too many patients chasing too little GH to an era in which there will be too much GH chasing too few patients.'

One of the first potential indications to be pursued was GH replacement in adult patients with GH deficiency (GHD) in two investigator-initiated trials $(6,7)$. This narrative review provides a personal account on the history of GH replacement in adults with a focus on the pivotal trials and the authors' own contributions.

\section{The pivotal trials}

The first placebo-controlled trial was performed in Denmark as a collaboration between adult and pediatric endocrinologists and published in 1989 (6). The patients $(n=22)$ all had childhood-onset GHD verified by at least two GH stimulation tests and had received GH replacement for a mean period of $\approx 7$ years, which was discontinued at least 6 months before study entry (mean duration of discontinuation $\approx 6$ years). The diagnosis was reconfirmed prior to the study by a clonidine stimulation test, and the mean age at study start was $\approx 24$ years. The study had a double-blind, placebo-controlled crossover design with 4-month treatment periods separated by a 4-month washout period and with the patients being studied at the end of each study period. The daily GH dose was $4 \mathrm{IU} / \mathrm{m}^{2}$ body surface $(\approx 1.1 \mathrm{mg} /$ day). The major outcomes included body composition in terms of muscle and fat volume of the thigh region assessed by CT scan, isometric muscle strength and aerobic exercise capacity assessed on a bicycle ergometer. In addition, glomerular filtration rate (GFR) and renal plasma flow (RPF) were measured isotopically. A significant increase in muscle volume $(P<0.01)$ and a significant reduction in fat volume $(P<0.05)$ were recorded together with a reduction in subscapular skinfold thickness $(P<0.01)$. This was accompanied by a significant increase in exercise capacity $(P<0.05)$, and an insignificant increase in muscle strength $(P=0.08)$. Both GFR and RPF increased $(P<0.01)$, which represented a normalization from subnormal levels. As expected, a treatment-induced increase in serum insulinlike growth factor 1 (IGF1) levels $(\mu \mathrm{g} / \mathrm{L})$ occurred $(96 \pm 9$ (placebo) vs $224 \pm 28(\mathrm{GH}), P<0.001)$.

Additional publications derived from the original trial revealed that GH replacement was associated with marked and concerted elevations (two- to fivefold) in the levels of serum osteocalcin and urinary excretion of deoxypyridinoline, indicative of increased bone remodeling $(8,9)$. Compelling evidence that $\mathrm{GH}$ promotes the extrathyroidal conversion of T4 to T3 was demonstrated for the first time in a placebo-controlled design (10). The patients also exhibited decreased sweating, which was reversed by GH (11). Finally, the original study was extended with an open phase of uninterrupted GH therapy, which documented continued improvement in body composition, exercise capacity, muscle strength and forearm bone mineral content $(12,13)$.

The second placebo-controlled trial was published 7 months later and differed in several respects (7). First, it mainly comprised patients with adult-onset GHD due to a pituitary tumor and its treatment. Second, it had a parallel design with a 6 months treatment period where each patient was examined before and after. The daily GH dose was $\approx 1.9 \mathrm{mg}$ and the mean age of the patients was $\approx 39$ years. The main outcomes were body composition assessed by conventional anthropometric measurements and total body potassium, and resting energy expenditure using indirect calorimetry. Lean body mass (LBM) increased significantly and was accompanied by a significant reduction in fat mass. This was associated with an increase in resting energy expenditure (REE) also after correction for LBM. In addition, evidence of GH-induced insulin resistance, as judged by increased fasting levels of glucose and insulin, was reported. Beneficial effects of GH replacement on exercise capacity and hyperlipidemia were also reported from the original study $(14,15,16)$.

\section{The syndrome of GH deficiency in adults}

In a review of the literature in 1992, Cuneo et al. introduced 'syndrome' as a term to describe the emerging clinical picture of GH deficiency in adults (GHDA) and 
the effects and side effects of GH replacement. (17) This concept was substantiated by studies from Sweden focusing on the phenotypical features of untreated GHDA $(18,19,20)$, and new data regarding the impact of GH replacement $(21,22,23,24)$. The syndrome overlaps with the metabolic syndrome as regards visceral obesity, hyperlipidemia and atherosclerosis. Moreover, evidence of premature cardiovascular morbidity and mortality was reported in GH-untreated hypopituitary adults $(25,26)$. Echocardiographic studies documented a stimulatory effect of GH on diastolic volume, stroke volume and myocardial contractility $(27,28,29,30)$. It was also observed that untreated GHDA was accompanied by reduced total body water and extracellular fluid volume (18), which reverses by $\mathrm{GH}$ replacement $(31,32)$. Indeed, fluid retention was noted as a frequent and dose-dependent side effect of GH treatment in adults. The mechanism involves sodium retention, but it is uncertain if it is mediated by activation of the renin angiotensin aldosterone system $(32,33)$, suppression of atrial natriuretic peptide (34) or a direct renal effect of GH or IGF1 $(35,36)$. Of note, this increase in hydration accounts for a limited part of the GH-induced changes in body composition (36). Impaired thermoregulation in response to the ambient outside temperature (37) and during strenuous exercise $(38,39)$ was also documented and partly attributed to reduced sweating capacity (11).

Insulin resistance, which is a hallmark of the metabolic syndrome, is not part of the GHDA syndrome, rather the opposite. GH antagonizes the effects of insulin on glucose metabolism in both the liver and skeletal muscle, which is causally linked to the lipolytic effects of GH (40). Indeed, increased insulin sensitivity and reactive hypoglycemia are characteristic of children and adolescents with GHD $(41,42,43)$, whereas the opposite is true for active acromegaly (44). Treatmentnaïve adult-onset GHD may, however, also exhibit insulin resistance (45), which likely represents the longterm consequences of obesity, reduced LBM and physical inactivity. The direct insulin antagonistic effect of GH is rapidly reversible $(46,47)$, and in normal physiology, it operates in the fasting state, where insulin activity is low $(48,49)$. However, daily subcutaneous GH injections in the evening are unable to fully imitate the endogenous GH pattern (50); therefore, GH replacement therapy invariably induces a certain degree of insulin resistance (49). Consequently, moderate elevations in the fasting levels of glucose and insulin are recorded in GHDA after $\mathrm{GH}$ replacement despite favorable changes in body composition (51).
The annual number of publications in the field of GHDA increased almost exponentially from two in 1989 to $>200$ in 1999 , which, in addition to corroborating the observations from the pivotal trials, added several original contributions (52). Dose-finding studies in different age groups were performed $(53,54,55)$, and it was confirmed that adult patients are highly sensitive to GH in terms of serum IGF1 generation and side effects (56), and that male patients are more responsive to $\mathrm{GH}$ as compared to females $(57,58)$. These and other data translated into guidelines for the diagnosis and management of GHDA issued by the Growth Hormone Research Society, which had been established in 1993 (59). The indication for GH replacement in GHDA was approved by the European Union in 1994 alongside with several other countries. In the same year, KIMS, an international outcomes research database with longitudinal data about GH therapy in adults, was initiated by Pharmacia and Upjohn and continued by Pfizer until 2012 with the inclusion of more than 16000 patients from 31 countries (https://medicaloutcomes. pfizer.com/kims). This resource has generated numerous peer-reviewed publications, also recently (60), and similar surveillance programs have been initiated by other providers of biosynthetic GH. In addition to this, several meta-analyses of published data on adult GH replacement have been published on outcomes such as cardiovascular risk factors (51), muscle strength and exercise capacity $(61,62)$, bone mineral density $(63,64)$, body composition (65) and cardiac function (66) (Fig. 1). In short, the metaanalyses confirmed and substantiated both the beneficial effects of GH replacement on body composition, bone mineral density, cardiac function and exercise capacity, as well as the side effects attributable to fluid retention and insulin resistance $(51,65)$ (Fig. 1).

It remains an open question whether GH replacement therapy improves patient-reported outcomes such as quality of life $(\mathrm{QoL})$ or cognitive function in the adult patient, since neither original studies nor meta-analyses provide unambiguous answers $(65,67,68,69)$. There is little doubt that QoL is reduced in the treatment-naïve patients, but it has proven difficult to document significant positive $\mathrm{GH}$ effects in placebo-controlled trials, and improvements in open trials are prone to bias and regression toward the means. Most QoL studies have utilized generic or diseasespecific questionnaires, which mainly record and depend on the respondents' remembrance and may fail to detect day-to-day experiences in real time; along the same line, it is possible that improvements in remembered QoL cease to provide increased satisfaction, a phenomenon coined hedonic adaptation (70). In this regard, it is interesting 


\begin{tabular}{|c|c|c|c|c|c|}
\hline \multirow{3}{*}{$\begin{array}{l}\text { Outcomes } \\
\text { Lean B mass }\end{array}$} & \multirow{3}{*}{$\begin{array}{c}\text { No. of trials } \\
19\end{array}$} & \multicolumn{2}{|c|}{ Treatment } & \multirow{3}{*}{$\begin{array}{c}\text { Weighted mean (SD) change } \\
\text { (GH-placebo) }\end{array}$} & \multirow{2}{*}{$\begin{array}{c}\text { Global effect size } \\
(95 \% \mathrm{Cl})\end{array}$} \\
\hline & & \multirow{2}{*}{$\begin{array}{l}\text { GH } \\
473\end{array}$} & \multirow{2}{*}{$\begin{array}{c}\text { Placebo } \\
474\end{array}$} & & \\
\hline & & & & & $\mapsto$ \\
\hline Fat mass & 13 & 352 & 345 & $-3.05 \mathrm{~kg}(3.29)$ & $\longmapsto$ \\
\hline BMI & 8 & 134 & 134 & $-0.12 \mathrm{~kg} / \mathrm{m}^{2}(1.40)$ & $\longmapsto$ \\
\hline TG & 11 & 202 & 203 & 0.07 mmol/liter (0.36) & $\longrightarrow$ \\
\hline HDL Chol. & 13 & 267 & 261 & 0.06 mmol/liter (0.09) & $\checkmark$ \\
\hline LDL Chol. & 13 & 255 & 248 & $-0.53 \mathrm{mmol} / \mathrm{liter}(0.29)$ & $\longmapsto$ \\
\hline Total Chol. & 15 & 310 & 306 & $-0.34 \mathrm{mmol} / \mathrm{liter}(0.31)$ & $\longmapsto$ \\
\hline D.B.P. & 10 & 200 & 201 & $-1.80 \mathrm{~mm} \mathrm{Hg}(3.77)$ & $\longmapsto$ \\
\hline S.B.P. & 9 & 190 & 191 & 2.06 mm Hg (5.34) & $\longmapsto$ \\
\hline Insulin & 11 & 192 & 194 & 8.66 pmol/liter (6.98) & $\longmapsto$ \\
\hline Glucose & 13 & 254 & 257 & $0.22 \mathrm{mmol} / \mathrm{liter}(0.14)$ & $\longmapsto$ \\
\hline
\end{tabular}

\section{Figure 1}

Results of meta-analysis of GH effects on cardiovascular risk factors from Maison et al. (51). (Copyright 2004, Oxford University Press). Chol., cholesterol; D.B.P., diastolic blood pressure; Lean B mass, Lean body mass; ns, nonsignificant; S.B.P., systolic blood pressure; TG, triglycerides.

that the most compelling - and beneficial - effects of adult GH replacement on QoL was recorded in a placebocontrolled crossover study, in which the spouse of the patient was asked to score the patient (71). Somewhat ironically, the National Institute for Health and Care Excellence in the United Kingdom (http://nice.org.uk/ guidance/ta64) requires impaired pretreatment QoL in order to initiate adult GH replacement, and it also demands discontinuation of treatment in case of a lack of QoL improvement after 9-month treatment (72).

\section{The transition phase}

Normal puberty marks the transition from childhood to adulthood and represents a period with marked physical changes including a pubertal growth spurt and the development of secondary sexual characteristics leading to attainment of adult reproductive capacity. Muscle and bone mass increase markedly during this period leading to the adult phenotype. These important physical changes depend in part on amplified GH secretion and action resulting in grossly elevated - even acromegalic - IGF1 levels in healthy subjects (73) (Fig. 2). Serum IGF1 levels remain elevated 2-5 years after peak height velocity, suggesting additional physiological actions of GH in this transition period on muscle and bone mass accrual. The transition phase starts in late puberty when final adult height is attained (mean age $\approx 15-17$ years) and terminates in early adulthood when peak bone mass is reached (mean age $\approx 20-23$ years).

Before 1985, GH replacement in childhood patients terminated as soon as a certain target height was achieved due to the scarce supply of pituitary GH, but the introduction of biosynthetic GH enabled continuation during the entire transition phase. The early adult GH replacement trials did not capture this important period,

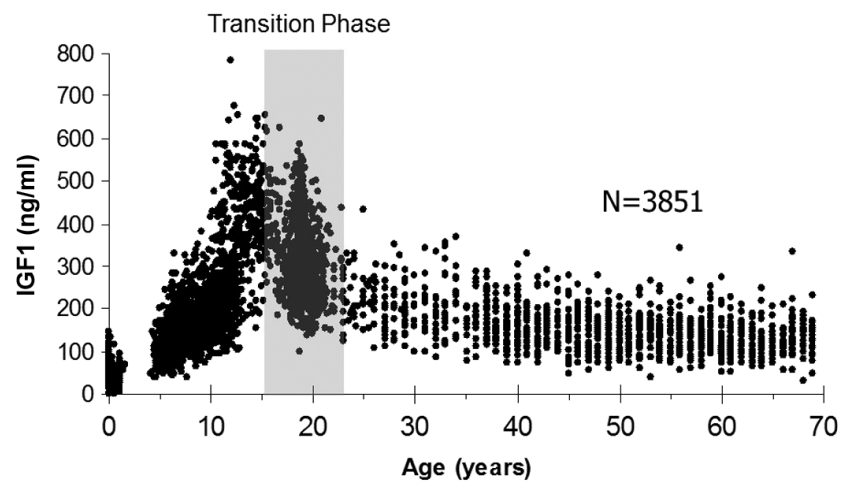

Figure 2

Serum IGF1 levels as a function of chronological age in 3851 healthy subjects of both sexes. The gray area indicates the duration of the transition phase. Modified from Juul et al. (13) 
but a prospective study reported that discontinuation of GH replacement in childhood-onset patients at the time of transition induced unfavorable changes in lipid profile and body composition (74). Subsequently, a Danish double-blind, placebo-controlled parallel study evaluated the effects of continuation vs discontinuation of GH after cessation of linear growth $(75,76)$. This study revealed that GH discontinuation resulted in decreased IGF1 as well as increased body fat and insulin sensitivity in the placebo group. After resumption of GH, LBM and IGF1 increased. Likewise, increased muscle volume of the thigh, muscle/ fat ratio and glucose oxidation rates increase following resumption of $\mathrm{GH}$. Comparable results were reported in 2004 from an open study of 12 -month continuation vs discontinuation of GH replacement (77).

Guidelines as regards management of GHD patients during the transition are available and a few issues merit mention here (78). First, a large proportion of GHD children exhibit normal stimulated GH secretion when retested after completion of GH treatment. Therefore, GH status and the indication for continued GH replacement in adulthood must be evaluated on an individual basis, which requires retesting unless there is strong evidence of either organic panhypopituitarism or a genetic cause of GHD. Second, the pediatric mode of $\mathrm{GH}$ dosing according to body size (weight or body surface) translates into high daily doses to achieve the appropriate pubertal growth response and the normal high pubertal IGF1 levels. These high GH doses are usually continued in the transition period even when growth is decelerating due to sex steroid-induced epiphyseal closure. Third, the proper management of transition patients includes patient involvement and a close collaboration between pediatric and adult endocrinologists (78).

\section{The senescence}

Endogenous GH production and serum IGF1 levels decline with age (79) in parallel with senescent changes in body composition and physical performance (Fig. 2). Interestingly, in midlife adults, abdominal adiposity is the strongest and negative determinant of endogenous GH secretion (80). Such correlations have led to speculations about a causal link between reduced GH production and the physical frailties of aging, which has been coined 'somatopause' (81). This controversial concept is beyond the scope of our review, but a meta-analysis of GH treatment studies in elderly subjects without overt pituitary disease record only limited positive effects and a high prevalence of GH-related side effects (82).
Despite the age-associated decline GH secretion, elderly patients aged $60-80$ years with panhypopituitarism due to well-defined pituitary pathology exhibit distinctly reduced GH and IGF1 levels as compared to age-matched controls (83). Moreover, GHDA patients in this age group seem to respond to $\mathrm{GH}$ replacement in the same manner as younger patients $(84,85,86)$. However, the GH dose requirement in order not to exceed IGF1 levels above the upper normal range for age and to avoid side effects, declines with chronological age (Fig. 3).

\section{GH replacement and mortality}

Increased mortality in hypopituitary patients due to cardiovascular disease is well established, and it has been difficult to resist the temptation to attribute this to unsubstituted GHD $(26,87)$. However, numerous underlying mechanisms may be equally - or more likely, for example additional features of hypopituitarism including the underlying disease, treatment complications and suboptimal substitution of additional pituitary deficiencies. It is also noteworthy, that mortality and cancer incidence are increased in acromegaly $(88,89)$, and that a strong inverse relation exists between activation of the IGF/insulin axis and longevity in many species (90, 91). Moreover, epidemiological human studies suggest an U-shaped association between serum IGF1 levels and all-cause mortality in the general population (92). Most importantly, controlled studies of GH replacement therapy with mortality as an endpoint do not exist and

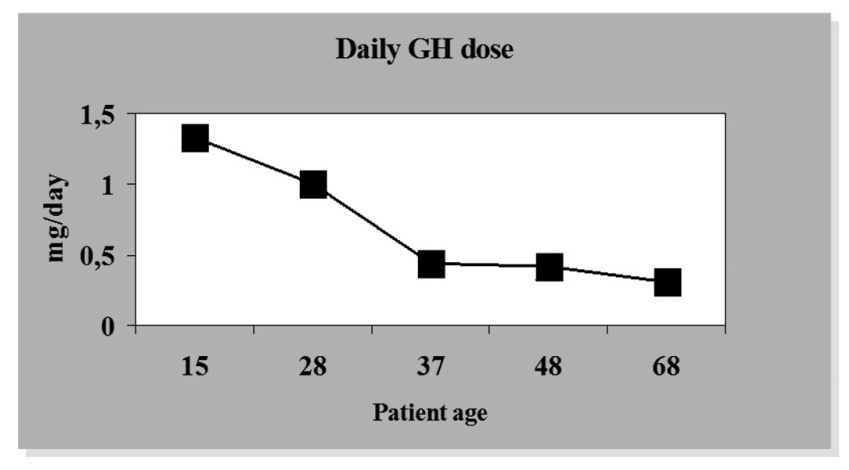

Figure 3

Daily GH dose $(\mathrm{mg})$ in GH-deficient adults employed to ensure a serum IGF1 level within the upper normal range for age as a function of chronological age. The figures are based on the authors own experience and data from the literature $(42,52$, $53,83,85)$. In addition to age, the $\mathrm{GH}$ dose also depends on gender. 
are very unlikely to appear in the future. An undisputable answer to the question whether GH replacement reduces mortality in GHD patients is therefore not available. However, observational studies in GHDA suggest that mortality is reduced in GH-replaced patients as compared to GH-untreated patients $(87,93,94,95)$. A meta-analysis reported that the standardized mortality rate was 2.40 (95\% CI: 1.46-3.34) in GH-untreated vs 1.15 (95\% CI: 1.05-1.24) in GH-treated patients (87), and an even larger difference was reported recently by Stochholm et al. (93).

\section{Discussion}

Adult subjects, including hypopituitary patients, were used to investigate the short-term metabolic effects of pituitary-derived human GH more than half a century ago, and it was speculated that GH replacement in GHDA could be beneficial $(2,3)$. This therapeutic option became feasible 25 years later with the introduction of biosynthetic GH, and a number of positive effects have been reported. Indeed, GH therapy in GHDA is probably the best-documented therapeutic indication in pituitary endocrinology in terms of placebo-controlled trials and observational studies. The change in body composition with reduced fat mass and increased LBM is the most robust effect. Most studies also record improvements in aerobic exercise capacity and cardiac function. As regards bone mass and strength, data from placebo-controlled trials for up to 1 year record increased bone turnover, but unchanged or even reduced bone mass (96), whereas one study of 18 months observed a significant increase in bone mineral density (BMD) of both the lumbar spine and the femoral neck (97). An increase in BMD is also reported in several open trials of prolonged GH replacement therapy, and it is believed by most that GH replacement initially increases bone remodeling, which transiently reduces $\mathrm{BMD}$, followed by a moderate but sustained increase at least in male patients (63). Whether this reduces the risk of osteoporotic fractures is uncertain, but observational studies suggest a reduced fracture risk (98). Whether QoL improves remains uncertain, since the results from placebo-controlled trials are ambiguous, and the results from open and observational studies are likely biased. The level of education is similar among GH-treated adult patients as compared to the background population, but a higher proportion of the patients are unemployed, retire earlier and are less likely to live with a partner (93, 99). These socioeconomic outcomes demonstrate that hypopituitarism remains a clinical challenge. Cancer risk is not increased with GH treatment, and mortality (100), if anything, is reduced $(93,94)$. The latter observation is reassuring even though it - to a large extent - is explained by selection bias (healthy user bias).

Side effects in terms of fluid retention and impaired insulin sensitivity are recognized, but they are dose dependent, rapidly reversible and probably of limited concern. Nevertheless, caution and vigilance are mandated to avoid overtreatment not least of the elderly patient. The daily GH dose requirement to avoid supernormal IGF1 levels and side effects may become as low as $0.1 \mathrm{mg}$ in male patients aged $\geq 70$ years (personal observation), which is more than ten-fold lower than the doses used in the early adult trials. This raises the question whether lifelong treatment is justified? In this regard, it should be recalled that although serum IGF1 is strictly $\mathrm{GH}$ dependent, its performance as a biomarker of GH treatment is far from perfect (101). The need for better biomarkers of GH treatment is accentuated by the recent introduction of long-acting GH preparations, since these compounds in contrast to daily subcutaneous GH therapy result in fluctuating serum IGF1 levels (102).

In conclusion, the first anecdotal report in 1962 of GH replacement in a patient with adult hypopituitarism concluded that 'observations will be needed in more cases to indicate whether the favorable effect was more than coincidental' (3). In 2018, it is safe to state that observations from numerous trials confirm the beneficial effects and justify this treatment modality.

Declaration of interest

J O L J has received lecture fees from Novo Nordisk, and lecture fees and unrestricted research grants from Pfizer.

\section{Funding}

This research did not receive any specific grant from any funding agency in the public, commercial or not-for-profit sector.

\section{Acknowledgements}

The authors wish to acknowledge the longtime collaboration with Niels Erik Skakkebæk and Jens Sandahl Christiansen in the field of GH deficiency.

\section{References}

1 Beck JC, Mcgarry EE, Dyrenfurth I \& Venning EH. Metabolic effects of human and monkey growth hormone in man. Science 1957125 884-885. (https://doi.org/10.1126/science.125.3253.884)

2 Raben MS. Growth hormone. New England Journal of Medicine 1962 266 31-35. (https://doi.org/10.1056/NEJM196201042660109)

3 Raben MS. Growth hormone. New England Journal of Medicine 1962 266 82-86. (https://doi.org/10.1056/NEJM196201112660207) 
4 Beardsley T. FDA ban on pituitary product. Nature 1985315 358-359.

5 Kaplan SL, Underwood LE, August GP, Bell JJ, Blethen SL, Blizzard RM, Brown DR, Foley TP, Hintz RL, Hopwood NJ et al. Clinical studies with recombinant-DNA-derived methionyl human growth hormone in growth hormone deficient children. Lancet 1986 1 697-700. (https://doi.org/10.1016/S0140-6736(86)91098-6)

6 Jorgensen JO, Pedersen SA, Thuesen L, Jorgensen J, IngemannHansen T, Skakkebaek NE \& Christiansen JS. Beneficial effects of growth hormone treatment in GH-deficient adults. Lancet 19891 1221-1225. (https://doi.org/10.1016/S0140-6736(89)92328-3)

7 Salomon F, Cuneo RC, Hesp R \& Sonksen PH. The effects of treatment with recombinant human growth hormone on body composition and metabolism in adults with growth hormone deficiency. New England Journal of Medicine 1989321 1797-1803. (https://doi.org/10.1056/NEJM198912283212605)

8 Johansen JS, Pedersen SA, Jorgensen JO, Riis BJ, Christiansen C, Christiansen JS \& Skakkebaek NE. Effects of growth hormone (GH) on plasma bone Gla protein in GH-deficient adults. Journal of Clinical Endocrinology and Metabolism 199070 916-919. (https://doi. org/10.1210/jcem-70-4-916)

9 Schlemmer A, Johansen JS, Pedersen SA, Jorgensen JO, Hassager C \& Christiansen C. The effect of growth hormone (GH) therapy on urinary pyridinoline cross-links in GH-deficient adults. Clinical Endocrinology 199135 471-476. (https://doi. org/10.1111/j.1365-2265.1991.tb00930.x)

10 Jorgensen JO, Pedersen SA, Laurberg P, Weeke J, Skakkebaek NE $\&$ Christiansen JS. Effects of growth hormone therapy on thyroid function of growth hormone-deficient adults with and without concomitant thyroxine-substituted central hypothyroidism. Journal of Clinical Endocrinology and Metabolism 198969 1127-1132. (https:// doi.org/10.1210/jcem-69-6-1127)

11 Pedersen SA, Welling K, Michaelsen KF, Jorgensen JO, Christiansen JS \& Skakkebaek NE. Reduced sweating in adults with growth hormone deficiency. Lancet 19892 681-682. (https://doi.org/10.1016/S01406736(89)90930-6)

12 Jorgensen JO, Pedersen SA, Thuesen L, Jorgensen J, Moller J, Muller J, Skakkebaek NE \& Christiansen JS. Long-term growth hormone treatment in growth hormone deficient adults. Acta Endocrinologica 1991125 449-453. (https://doi.org/10.1530/acta.0.1250449)

13 Juul A, Pedersen SA, Sorensen S, Winkler K, Jorgensen JO, Christiansen JS \& Skakkebaek NE. Growth hormone (GH) treatment increases serum insulin-like growth factor binding protein-3, bone isoenzyme alkaline phosphatase and forearm bone mineral content in young adults with GH deficiency of childhood onset. European Journal of Endocrinology 1994131 41-49. (https://doi.org/10.1530/eje.0.1310041)

14 Cuneo RC, Salomon F, Wiles CM, Hesp R \& Sonksen PH. Growth hormone treatment in growth hormone-deficient adults. II. Effects on exercise performance. Journal of Applied Physiology $1991 \mathbf{7 0}$ 695-700. (https://doi.org/10.1152/jappl.1991.70.2.695)

15 Cuneo RC, Salomon F, Wiles CM, Hesp R \& Sonksen PH. Growth hormone treatment in growth hormone-deficient adults. I. Effects on muscle mass and strength. Journal of Applied Physiology 199170 688-694. (https://doi.org/10.1152/jappl.1991.70.2.688)

16 Cuneo RC, Salomon F, Watts GF, Hesp R \& Sonksen PH. Growth hormone treatment improves serum lipids and lipoproteins in adults with growth hormone deficiency. Metabolism: Clinical and Experimental 199342 1519-1523. (https://doi.org/10.1016/00260495(93)90145-E)

17 Cuneo RC, Salomon F, McGauley GA \& Sonksen PH. The growth hormone deficiency syndrome in adults. Clinical Endocrinology 1992 37 387-397. (https://doi.org/10.1111/j.1365-2265.1992.tb02347.x)

18 Rosen T, Bosaeus I, Tolli J, Lindstedt G \& Bengtsson BA. Increased body fat mass and decreased extracellular fluid volume in adults with growth hormone deficiency. Clinical Endocrinology 199338 63-71. (https://doi.org/10.1111/j.1365-2265.1993.tb00974.x)
19 Rosen T, Eden S, Larson G, Wilhelmsen L \& Bengtsson BA. Cardiovascular risk factors in adult patients with growth hormone deficiency. Acta Endocrinologica 1993129 195-200. (https://doi. org/10.1530/acta.0.1290195)

20 Rosen T, Hansson T, Granhed H, Szucs J \& Bengtsson BA. Reduced bone mineral content in adult patients with growth hormone deficiency. Acta Endocrinologica 1993129 201-206. (https://doi. org/10.1530/acta.0.1290201)

21 Jorgensen JO, Thuesen L, Muller J, Ovesen P, Skakkebaek NE \& Christiansen JS. Three years of growth hormone treatment in growth hormone-deficient adults: near normalization of body composition and physical performance. European Journal of Endocrinology 1994130 224-228. (https://doi.org/10.1530/eje.0.1300224)

22 Bengtsson BA, Eden S, Lonn L, Kvist H, Stokland A, Lindstedt G, Bosaeus I, Tölli J, Sjöström L \& Isaksson OG. Treatment of adults with growth hormone (GH) deficiency with recombinant human GH. Journal of Clinical Endocrinology and Metabolism 199376 309-317. (https://doi.org/10.1210/jcem.76.2.8432773)

23 Whitehead HM, Boreham C, McIlrath EM, Sheridan B, Kennedy L, Atkinson AB \& Hadden DR. Growth hormone treatment of adults with growth hormone deficiency: results of a 13-month placebo controlled cross-over study. Clinical Endocrinology 199236 45-52. (https://doi.org/10.1111/j.1365-2265.1992.tb02901.x)

24 Jorgensen JO, Vahl N, Hansen TB, Thuesen L, Hagen C \& Christiansen JS. Growth hormone versus placebo treatment for one year in growth hormone deficient adults: increase in exercise capacity and normalization of body composition. Clinical Endocrinology 199645 681-688. (https://doi.org/10.1046/j.13652265.1996.8720883.x)

25 Markussis V, Beshyah SA, Fisher C, Sharp P, Nicolaides AN \& Johnston DG. Detection of premature atherosclerosis by highresolution ultrasonography in symptom-free hypopituitary adults. Lancet 1992340 1188-1192. (https://doi.org/10.1016/01406736(92)92892-J)

26 Rosen T \& Bengtsson BA. Premature mortality due to cardiovascular disease in hypopituitarism. Lancet 1990336 285-288. (https://doi. org/10.1016/0140-6736(90)91812-O)

27 Beshyah SA, Shahi M, Skinner E, Sharp P, Foale R \& Johnston DG. Cardiovascular effects of growth hormone replacement therapy in hypopituitary adults. European Journal of Endocrinology $1994 \mathbf{1 3 0}$ 451-458. (https://doi.org/10.1530/eje.0.1300451)

28 Thuesen L, Christiansen JS, Sorensen KE, Jorgensen JO, Orskov H \& Henningsen P. Increased myocardial contractility following growth hormone administration in normal man. An echocardiographic study. Danish Medical Bulletin 198835 193-196.

29 Thuesen L, Jorgensen JO, Muller JR, Kristensen BO, Skakkebaek NE, Vahl N \& Christiansen JS. Short and long-term cardiovascular effects of growth hormone therapy in growth hormone deficient adults. Clinical Endocrinology 199441 615-620. (https://doi. org/10.1111/j.1365-2265.1994.tb01827.x)

30 Cuneo RC, Salomon F, Wilmshurst P, Byrne C, Wiles CM, Hesp R \& Sönksen PH. Cardiovascular effects of growth hormone treatment in growth-hormone-deficient adults: stimulation of the reninaldosterone system. Clinical Science 199181 587-592. (https://doi. org/10.1042/cs0810587)

31 Moller J, Frandsen E, Fisker S, Jorgensen JO \& Christiansen JS. Decreased plasma and extracellular volume in growth hormone deficient adults and the acute and prolonged effects of GH administration: a controlled experimental study. Clinical Endocrinology 199644 533-539. (https://doi.org/10.1046/j.13652265.1996.728550.x)

32 Moller J, Jorgensen JO, Frandsen E, Laursen T \& Christiansen JS. Body fluids, circadian blood pressure and plasma renin during growth hormone administration: a placebo-controlled study with two growth hormone doses in healthy adults. Scandinavian Journal 
of Clinical and Laboratory Investigation 199555 663-669. (https://doi. org/10.3109/00365519509075396)

33 Moller J, Moller N, Frandsen E, Wolthers T, Jorgensen JO \& Christiansen JS. Blockade of the renin-angiotensin-aldosterone system prevents growth hormone-induced fluid retention in humans. American Journal of Physiology 1997272 E803-E808. (https://doi.org/10.1152/ajpendo.1997.272.5.E803)

34 Moller J, Jorgensen JO, Moller N, Hansen KW, Pedersen EB \& Christiansen JS. Expansion of extracellular volume and suppression of atrial natriuretic peptide after growth hormone administration in normal man. Journal of Clinical Endocrinology and Metabolism 199172 768-772. (https://doi.org/10.1210/jcem-72-4-768)

35 Kamenicky P, Mazziotti G, Lombes M, Giustina A \& Chanson P. Growth hormone, insulin-like growth factor-1, and the kidney: pathophysiological and clinical implications. Endocrine Reviews 2014 35 234-281. (https://doi.org/10.1210/er.2013-1071)

36 de Boer H, Blok GJ \& Van der Veen EA. Clinical aspects of growth hormone deficiency in adults. Endocrine Reviews 199516 63-86. (https://doi.org/10.1210/edrv-16-1-63)

37 Juul A \& Skakkebaek NE. Growth hormone deficiency and hyperthermia. Lancet 1991338 887. (https://doi.org/10.1016/01406736(91)91543-4)

38 Juul A, Behrenscheer A, Tims T, Nielsen B, Halkjaer-Kristensen J \& Skakkebaek NE. Impaired thermoregulation in adults with growth hormone deficiency during heat exposure and exercise. Clinical Endocrinology 199338 237-244. (https://doi. org/10.1111/j.1365-2265.1993.tb01001.x)

39 Juul A, Hjortskov N, Jepsen LT, Nielsen B, Halkjaer-Kristensen J, Vahl N, Jørgensen JO, Christiansen JS \& Skakkebaek NE. Growth hormone deficiency and hyperthermia during exercise: a controlled study of sixteen GH-deficient patients. Journal of Clinical Endocrinology and Metabolism 199580 3335-3340. (https://doi. org/10.1210/jcem.80.11.7593447)

40 Nielsen S, Moller N, Christiansen JS \& Jorgensen JO. Pharmacological antilipolysis restores insulin sensitivity during growth hormone exposure. Diabetes 200150 2301-2308. (https://doi.org/10.2337/ diabetes.50.10.2301)

41 Press M, Notarfrancesco A \& Genel M. Risk of hypoglycaemia with alternate-day growth hormone injections. Lancet 1987 1002-1004. (https://doi.org/10.1016/S0140-6736(87)92270-7)

42 Jorgensen JO, Flyvbjerg A, Lauritzen T, Alberti KG, Orskov H \& Christiansen JS. Dose-response studies with biosynthetic human growth hormone (GH) in GH-deficient patients. Journal of Clinical Endocrinology and Metabolism 198867 36-40. (https://doi. org/10.1210/jcem-67-1-36)

43 Jorgensen JO, Moller J, Alberti KG, Schmitz O, Christiansen JS, Orskov H \& Moller N. Marked effects of sustained low growth hormone (GH) levels on day-to-day fuel metabolism: studies in GH-deficient patients and healthy untreated subjects. Journal of Clinical Endocrinology and Metabolism 199377 1589-1596. (https:// doi.org/10.1210/jcem.77.6.8263146)

44 Moller N, Schmitz O, Joorgensen JO, Astrup J, Bak JF, Christensen SE, Alberti KG \& Weeke J. Basal- and insulin-stimulated substrate metabolism in patients with active acromegaly before and after adenomectomy. Journal of Clinical Endocrinology and Metabolism 1992 74 1012-1019. (https://doi.org/10.1210/jcem.74.5.1569148)

45 Johansson JO, Fowelin J, Landin K, Lager I \& Bengtsson BA. Growth hormone-deficient adults are insulin-resistant. Metabolism: Clinical and Experimental 199544 1126-1129. (https://doi.org/10.1016/00260495(95)90004-7)

46 Zierler KL \& Rabinowitz D. Roles of insulin and growth hormone, based on studies of forearm metabolism in man. Medicine 1963 42:385-402. (https://doi.org/10.1097/00005792-196311000-00002)

47 Krusenstjerna-Hafstrom T, Clasen BF, Moller N, Jessen N, Pedersen SB, Christiansen JS \& Jørgensen JO. Growth hormone (GH)-induced insulin resistance is rapidly reversible: an experimental study in
GH-deficient adults. Journal of Clinical Endocrinology and Metabolism 201196 2548-2557. (https://doi.org/10.1210/jc.2011-0273)

48 Rabinowitz D \& Zierler KL. A metabolic regulating device based on the actions of human growth hormone and of insulin, singly and together, on the human forearm. Nature 1963199 913-915. (https:// doi.org/10.1038/199913a0)

49 Moller N \& Jorgensen JO. Effects of growth hormone on glucose, lipid, and protein metabolism in human subjects. Endocrine Reviews 200930 152-177. (https://doi.org/10.1210/er.2008-0027)

50 Jorgensen JO. Human growth hormone replacement therapy: pharmacological and clinical aspects. Endocrine Reviews 199112 189-207. (https://doi.org/10.1210/edrv-12-3-189)

51 Maison P, Griffin S, Nicoue-Beglah M, Haddad N, Balkau B \& Chanson P. Impact of growth hormone (GH) treatment on cardiovascular risk factors in GH-deficient adults: a Metaanalysis of Blinded, Randomized, Placebo-Controlled Trials. Journal of Clinical Endocrinology and Metabolism 200489 2192-2199. (https://doi. org/10.1210/jc.2003-030840)

52 Carroll PV, Christ ER, Bengtsson BA, Carlsson L, Christiansen JS, Clemmons D, Hintz R, Ho K, Laron Z, Sizonenko P et al. Growth hormone deficiency in adulthood and the effects of growth hormone replacement: a review. Growth Hormone Research Society Scientific Committee. Journal of Clinical Endocrinology and Metabolism $1998 \mathbf{8 3}$ 382-395. (https://doi.org/10.1210/jcem.83.2.4594)

53 Moller J, Jorgensen JO, Lauersen T, Frystyk J, Naeraa RW, Orskov H \& Christiansen JS. Growth hormone dose regimens in adult GH deficiency: effects on biochemical growth markers and metabolic parameters. Clinical Endocrinology 199339 403-408. (https://doi. org/10.1111/j.1365-2265.1993.tb02386.x)

54 de Boer H, Blok GJ, Popp-Snijders C, Stuurman L, Baxter RC \& van der Veen E. Monitoring of growth hormone replacement therapy in adults, based on measurement of serum markers. Journal of Clinical Endocrinology and Metabolism 199681 1371-1377. (https://doi. org/10.1210/jcem.81.4.8636336)

55 Johannsson G, Rosen T \& Bengtsson BA. Individualized dose titration of growth hormone (GH) during GH replacement in hypopituitary adults. Clinical Endocrinology 199747 571-581. (https://doi. org/10.1046/j.1365-2265.1997.3271123.x)

56 Cuneo RC, Judd S, Wallace JD, Perry-Keene D, Burger H, LimTio S, Strauss B, Stockigt J, Topliss D, Alford F et al. The Australian multicenter trial of growth hormone (GH) treatment in GH-deficient adults. Journal of Clinical Endocrinology and Metabolism $1998 \mathbf{8 3}$ 107-116. (https://doi.org/10.1210/jcem.83.1.4482)

57 Johannsson G, Bjarnason R, Bramnert M, Carlsson LM, Degerblad M, Manhem P, Rośen T, Thorén M \& Bengtsson BA. The individual responsiveness to growth hormone (GH) treatment in GH-deficient adults is dependent on the level of GH-binding protein, body mass index, age, and gender. Journal of Clinical Endocrinology and Metabolism 199681 1575-1581. (https://doi.org/10.1210/ jcem.81.4.8636370)

58 Burman P, Johansson AG, Siegbahn A, Vessby B \& Karlsson FA Growth hormone (GH)-deficient men are more responsive to $\mathrm{GH}$ replacement therapy than women. Journal of Clinical Endocrinology and Metabolism 199782 550-555. (https://doi.org/10.1210/ jcem.82.2.3776)

59 Consensus guidelines for the diagnosis and treatment of adults with growth hormone deficiency: summary statement of the Growth Hormone Research Society Workshop on Adult Growth Hormone Deficiency. Journal of Clinical Endocrinology and Metabolism $1998 \mathbf{8 3}$ 379-381. (https://doi.org/10.1210/jcem.83.2.4611)

60 Krzyzanowska-Mittermayer K, Mattsson AF, Maiter D, FeldtRasmussen U, Camacho-Hubner C, Luger A \& Abs R. New neoplasm during GH replacement in adults with pituitary deficiency following malignancy: a KIMS analysis. Journal of Clinical Endocrinology and Metabolism 2018103 523-531. (https://doi.org/10.1210/jc.201701899) 
61 Rubeck KZ, Bertelsen S, Vestergaard P \& Jorgensen JO. Impact of GH substitution on exercise capacity and muscle strength in GH-deficient adults: a meta-analysis of blinded, placebo-controlled trials. Clinical Endocrinology 200971 860-866. (https://doi. org/10.1111/j.1365-2265.2009.03592.x)

62 Widdowson WM \& Gibney J. The effect of growth hormone replacement on exercise capacity in patients with GH deficiency: a metaanalysis. Journal of Clinical Endocrinology and Metabolism 200893 4413-4417. (https://doi.org/10.1210/jc.2008-1239)

63 Barake M, Klibanski A \& Tritos NA. Effects of recombinant human growth hormone therapy on bone mineral density in adults with growth hormone deficiency: a meta-analysis. Journal of Clinical Endocrinology and Metabolism 201499 852-860. (https://doi. org/10.1210/jc.2013-3921)

64 Xue P, Wang Y, Yang J \& Li Y. Effects of growth hormone replacement therapy on bone mineral density in growth hormone deficient adults: a meta-analysis. International Journal of Endocrinology 2013 2013 216107. (https://doi.org/10.1155/2013/216107)

65 Hazem A, Elamin MB, Bancos I, Malaga G, Prutsky G, Domecq JP, Elraiyah TA, Abu Elnour NO, Prevost Y, Almandoz JP et al. Body composition and quality of life in adults treated with GH therapy: a systematic review and meta-analysis. European Journal of Endocrinology 2012166 13-20. (https://doi.org/10.1530/EJE-11-0558)

66 Maison P \& Chanson P. Cardiac effects of growth hormone in adults with growth hormone deficiency: a meta-analysis. Circulation 2003108 2648-2652. (https://doi.org/10.1161/01. CIR.0000100720.01867.1D)

67 Deijen JB, Arwert LI, Witlox J \& Drent ML. Differential effect sizes of growth hormone replacement on Quality of Life, well-being and health status in growth hormone deficient patients: a metaanalysis. Health and Quality of Life Outcomes 20053 63. (https://doi. org/10.1186/1477-7525-3-63)

68 Arwert LI, Deijen JB, Witlox J \& Drent ML. The influence of growth hormone $(\mathrm{GH})$ substitution on patient-reported outcomes and cognitive functions in GH-deficient patients: a meta-analysis. Growth Hormone and IGF Research 200515 47-54. (https://doi.org/10.1016/j. ghir.2004.11.004)

69 Falleti MG, Maruff P, Burman P \& Harris A. The effects of growth hormone $(\mathrm{GH})$ deficiency and $\mathrm{GH}$ replacement on cognitive performance in adults: a meta-analysis of the current literature. Psychoneuroendocrinology 200631 681-691. (https://doi. org/10.1016/j.psyneuen.2006.01.005)

70 Kahneman D, Krueger AB, Schkade DA, Schwarz N \& Stone AA A survey method for characterizing daily life experience: the day reconstruction method. Science 2004306 1776-1780. (https://doi. org/10.1126/science.1103572)

71 Burman P, Broman JE, Hetta J, Wiklund I, Erfurth EM, Hagg E \& Karlsson FA. Quality of life in adults with growth hormone $(\mathrm{GH})$ deficiency: response to treatment with recombinant human GH in a placebo-controlled 21-month trial. Journal of Clinical Endocrinology and Metabolism 199580 3585-3590. (https://doi.org/10.1210/ jcem.80.12.8530603)

72 National Institute for Health and Clinical Excellence. Human growth hormone (somatropin) in adults with growth hormone deficiency. London: National Institute for Health and Clinical Excellence, 2003.

73 Juul A, Bang P, Hertel NT, Main K, Dalgaard P, Jorgensen K, Müller J, Hall K \& Skakkebaek NE. Serum insulin-like growth factor-I in 1030 healthy children, adolescents, and adults: relation to age, sex, stage of puberty, testicular size, and body mass index. Journal of Clinical Endocrinology and Metabolism 199478 744-752. (https://doi. org/10.1210/jcem.78.3.8126152)

74 Johannsson G, Albertsson-Wikland K \& Bengtsson BA. Discontinuation of growth hormone $(\mathrm{GH})$ treatment: metabolic effects in GH-deficient and GH-sufficient adolescent patients compared with control subjects. Swedish Study Group for Growth Hormone Treatment in Children. Journal of Clinical Endocrinology and Metabolism 199984 4516-4524. (https://doi.org/10.1210/ jcem.84.12.6176)

75 Vahl N, Juul A, Jorgensen JO, Orskov H, Skakkebaek NE \& Christiansen JS. Continuation of growth hormone (GH) replacement in GH-deficient patients during transition from childhood to adulthood: a two-year placebo-controlled study. Journal of Clinical Endocrinology and Metabolism 200085 1874-1881. (https://doi. org/10.1210/jcem.85.5.6598)

76 Norrelund H, Vahl N, Juul A, Moller N, Alberti KG, Skakkebaek NE, Christiansen JS \& Jørgensen JO. Continuation of growth hormone (GH) therapy in GH-deficient patients during transition from childhood to adulthood: impact on insulin sensitivity and substrate metabolism. Journal of Clinical Endocrinology and Metabolism $2000 \mathbf{8 5}$ 1912-1917. (https://doi.org/10.1210/jcem.85.5.6613)

77 Carroll PV, Drake WM, Maher KT, Metcalfe K, Shaw NJ, Dunger DB, Cheetham TD, Camacho-Hübner C, Savage MO \& Monson JP. Comparison of continuation or cessation of growth hormone $(\mathrm{GH})$ therapy on body composition and metabolic status in adolescents with severe GH deficiency at completion of linear growth. Journal of Clinical Endocrinology and Metabolism 200489 3890-3895. (https:// doi.org/10.1210/jc.2003-031588)

78 Clayton PE, Cuneo RC, Juul A, Monson JP, Shalet SM \& Tauber M. Consensus statement on the management of the GH-treated adolescent in the transition to adult care. European Journal of Endocrinology 2005152 165-170. (https://doi.org/10.1530/eje.1.01829)

79 Veldhuis JD, Roelfsema F, Keenan DM \& Pincus S. Gender, age, body mass index, and IGF-I individually and jointly determine distinct GH dynamics: analyses in one hundred healthy adults. Journal of Clinical Endocrinology and Metabolism 201196 115-121. (https://doi. org/10.1210/jc.2010-1669)

80 Vahl N, Jorgensen JO, Skjaerbaek C, Veldhuis JD, Orskov H \& Christiansen JS. Abdominal adiposity rather than age and sex predicts mass and regularity of GH secretion in healthy adults. American Journal of Physiology 1997272 E1108-E1116. (https://doi. org/10.1152/ajpendo.1997.272.6.E1108)

81 Toogood AA. The somatopause: an indication for growth hormone therapy? Treatments in Endocrinology 20043 201-209. (https://doi. org/10.2165/00024677-200403040-00001)

82 Liu H, Bravata DM, Olkin I, Nayak S, Roberts B, Garber AM \& Hoffman AR. Systematic review: the safety and efficacy of growth hormone in the healthy elderly. Annals of Internal Medicine 2007146 104-115. (https://doi.org/10.7326/0003-4819-146-2-20070116000005)

83 Toogood AA, O'Neill PA \& Shalet SM. Beyond the somatopause: growth hormone deficiency in adults over the age of 60 years. Journal of Clinical Endocrinology and Metabolism 199681 460-465. (https:// doi.org/10.1210/jcem.81.2.8636250)

84 Toogood AA \& Shalet SM. Growth hormone replacement therapy in the elderly with hypothalamic-pituitary disease: a dose-finding study. Journal of Clinical Endocrinology and Metabolism 199984 131-136. (https://doi.org/10.1210/jcem.84.1.5408)

85 Fernholm R, Bramnert M, Hagg E, Hilding A, Baylink DJ, Mohan S \& Thorén M. Growth hormone replacement therapy improves body composition and increases bone metabolism in elderly patients with pituitary disease. Journal of Clinical Endocrinology and Metabolism 2000 85 4104-4112. (https://doi.org/10.1210/jcem.85.11.6949)

86 Franco C, Johannsson G, Bengtsson B-AK \& Svensson J. Baseline characteristics and effects of growth hormone therapy over two years in younger and elderly adults with adult onset GH deficiency. Journal of Clinical Endocrinology and Metabolism 200691 4408-4414. (https:// doi.org/10.1210/jc.2006-0887)

87 Pappachan JM, Raskauskiene D, Kutty VR \& Clayton RN. Excess mortality associated with hypopituitarism in adults: a meta-analysis of observational studies. Journal of Clinical Endocrinology and Metabolism 2015100 1405-1411. (https://doi.org/10.1210/jc.20143787) 
88 Dal J, Leisner MZ, Hermansen K, Farkas DK, Bengtsen M, Kistorp C, Nielsen EH, Andersen M, Feldt-Rasmussen U et al. Cancer Incidence in Patients with Acromegaly: a cohort study and meta-analysis of the literature. Journal of Clinical Endocrinology and Metabolism 2018. Epub. (https://doi.org/10.1210/jc.2017-02457)

89 Holdaway IM, Bolland MJ \& Gamble GD. A meta-analysis of the effect of lowering serum levels of GH and IGF-I on mortality in acromegaly. European Journal of Endocrinology 2008159 89-95. (https://doi.org/10.1530/EJE-08-0267)

90 Fontana L \& Partridge L. Promoting health and longevity through diet: from model organisms to humans. Cell 2015161 106-118. (https://doi.org/10.1016/j.cell.2015.02.020)

91 Junnila RK, List EO, Berryman DE, Murrey JW \& Kopchick JJ. The GH/IGF-1 axis in ageing and longevity. Nature Reviews Endocrinology 20139 366-376. (https://doi.org/10.1038/nrendo.2013.67)

92 Burgers AM, Biermasz NR, Schoones JW, Pereira AM, Renehan AG, Zwahlen M, Egger M \& Dekkers OM. Meta-analysis and doseresponse metaregression: circulating insulin-like growth factor I (IGF-I) and mortality. Journal of Clinical Endocrinology and Metabolism 201196 2912-2920. (https://doi.org/10.1210/jc.2011-1377)

93 Stochholm K, Berglund A, Juul S, Gravholt CH \& Christiansen JS. Socioeconomic factors do not but GH treatment does affect mortality in adult-onset growth hormone deficiency. Journal of Clinical Endocrinology and Metabolism 201499 4141-4148. (https://doi. org/10.1210/jc.2014-1814)

94 Olsson DS, Trimpou P, Hallen T, Bryngelsson IL, Andersson E, Skoglund T, Bengtsson BÅ, Johannsson G2 \& Nilsson AG. Life expectancy in patients with pituitary adenoma receiving growth hormone replacement. European Journal of Endocrinology 2017176 67-75. (https://doi.org/10.1530/EJE-16-0450)

95 Berglund A, Gravholt CH, Olsen MS, Christiansen JS \& Stochholm K. Growth hormone replacement does not increase mortality in patients with childhood-onset growth hormone deficiency. Clinical Endocrinology 201583 677-683. (https://doi.org/10.1111/cen.12848)

96 Hansen TB, Brixen K, Vahl N, Jorgensen JO, Christiansen JS, Mosekilde L \& Hagen C. Effects of 12 months of growth hormone
(GH) treatment on calciotropic hormones, calcium homeostasis, and bone metabolism in adults with acquired GH deficiency: a double blind, randomized, placebo-controlled study. Journal of Clinical Endocrinology and Metabolism 199681 3352-3359. (https://doi. org/10.1210/jcem.81.9.8784096)

97 Baum HB, Biller BM, Finkelstein JS, Cannistraro KB, Oppenhein DS, Schoenfeld DA, Michel TH, Wittink H \& Klibanski A. Effects of physiologic growth hormone therapy on bone density and body composition in patients with adult-onset growth hormone deficiency. A randomized, placebo-controlled trial. Annals of Internal Medicine 1996125 883-890. (https://doi.org/10.7326/0003-4819. 125-11-199612010-00003)

98 Mo D, Fleseriu M, Qi R, Jia N, Child CJ, Bouillon R \& Hardin DS. Fracture risk in adult patients treated with growth hormone replacement therapy for growth hormone deficiency: a prospective observational cohort study. Lancet Diabetes and Endocrinology 20153 331-338. (https://doi.org/10.1016/S2213-8587(15)00098-4)

99 Holmer H, Svensson J, Rylander L, Johannsson G, Rosen T, Bengtsson BA, Thorén M, Höybye C, Degerblad M, Bramnert M et al. Psychosocial health and levels of employment in 851 hypopituitary Swedish patients on long-term GH therapy. Psychoneuroendocrinology 201338 842-852. (https://doi.org/10.1016/j.psyneuen.2012.09.008)

100 Stochholm K \& Johannsson G. Reviewing the safety of GH replacement therapy in adults. Growth Hormone and IGF Research 201525 149-157. (https://doi.org/10.1016/j.ghir.2015.06.006)

101 Johannsson G, Bidlingmaier M, Biller BMK, Boguszewski M, Casanueva FF, Chanson P, Clayton PE, Choong CS, Clemmons D, Dattani M et al. Growth Hormone Research Society perspective on biomarkers of GH action in children and adults. Endocrine Connections 20187 R126-R134. (https://doi.org/10.1530/EC-18-0047)

102 Christiansen JS, Backeljauw PF, Bidlingmaier M, Biller BMK, Boguszewski MCS, Casanueva FF, Chanson P, Chatelain P, Choong CS, Clemmons DR et al. Growth Hormone Research Society perspective on the development of long-acting growth hormone preparations. European Journal of Endocrinology 2016174 C1-C8. (https://doi.org/10.1530/EJE-16-0111)

Received 10 April 2018

Revised version received 25 April 2018

Accepted 1 May 2018 